\title{
The Phenomenology of Language and the Metaphysicalizing of the Real
}

\author{
Robert D. Stolorow ${ }^{1}$ \\ Institute of Contemporary Psychoanalysis, Los Angeles \\ George E. Atwood \\ Providence, Rhode Island
}

\begin{abstract}
This essay joins Wilhelm Dilthey's conception of the metaphysical impulse as a flight from the tragedy of human finitude with Ludwig Wittgenstein's understanding of how language bewitches intelligence. We contend that there are features of the phenomenology of language that play a constitutive and pervasive role in the formation of metaphysical illusion.
\end{abstract}

\section{Introduction}

Philosophy is a battle against the bewitchment of our intelligence by means of our language. Ludwig Wittgenstein, 1953, section 109

An entire mythology is stored within our language. Ludwig Wittgenstein, 1967/1993, p. 133

Soon after beginning work on a project on the phenomenology of language, we came upon Andrew Inkpin's (2016) recent book, Disclosing the World: On the Phenomenology of Language. The title of the book alone left us wondering whether there is anything remaining for us to illuminate. Indeed there is. Drawing on the works of Heidegger, Merleau-Ponty, and Wittgenstein, Inkpin presents an elegant and comprehensive account of how the experience of language and its principles of organization play a constitutive, usually prereflective role in disclosing and opening up the world. He does not, however, pay systematic attention to how the experience of language, in Wittgenstein's (1953) words, bewitches intelligence by playing a constitutive role in the formation of metaphysical illusion - the subject matter of this essay.

Wittgenstein's account of how language bewitches one's intelligence is a singular achievement in the phenomenology of language. In section 426 of Philosophical Investigations Wittgenstein famously claims that the meaning of a word is to be found in the "actual use" of it, and he contrasts this understanding with the projection of a picture:

1 Correspondence concerning this article should be addressed to Robert D. Stolorow, Ph.D., Ph.D. Email: robertdstolorow@gmail.com

Language and Psychoanalysis, 2017, 6 (1), 4-9

http://dx.doi.org/10.7565/landp.v6i1.1564 
A picture is conjured up which seems to fix the sense unambiguously. The actual

use, compared with that suggested by the picture, seems like something muddied.

.... [T]he form of expression we use seems to have been designed for a god, who

knows what we cannot know; he sees the whole of each of those infinite series

and he sees into human consciousness. (Wittgenstein, 1953, section 426)

Wittgenstein is claiming here that when one projects a picture as the meaning of a word, it gives one the illusion of a God's-eye view of the word's referent as a thing-initself, an illusory clarity that one much prefers over the "muddied" view given in the understanding that the actual meaning of a word is to be found in its multiple and shifting contexts of use. When the illusory picture is then imagined as ultimately real, the word has become transformed into a metaphysical entity. In place of the "muddied" view given by contexts of use - finite, contingent, unstable, transient - one can imagine the clear outlines of an everlasting entity. Metaphysical illusion, mediated by reified pictures, replaces the finitude and transience of existence with a God's-eye view of an irreducibly absolute and eternally changeless reality (Stolorow \& Atwood, 2013). A bewitchment of intelligence by language is thereby accomplished!

In what follows, we seek to expand Wittgenstein's analysis of bewitchment of intelligence by language into a broader account of how one's prereflective experience of language shapes one's sense of the real.

\section{The Illusion of Spatial Location}

A good example, also discussed by Wittgenstein, is the use of words that properly describe geometric space to "locate" emotional experience. People speak of their inner experiences, their inner feelings, getting their anger (from the inside) out, taking things in, looking inward (introspection), etc. These expressions correspond to Descartes's picture of the mind as a thinking thing that has an inside with contents and that looks out upon an external world from which it is separated. The picture of the mind as an entity located in Cartesian space - a picture institutionalized in the experience of everyday language - reifies what Zahavi (2005) calls experiential selfhood, the "mineness" of one's experiences. Such a picture prereflectively transforms the vulnerable, context-dependent, and evanescent experience of mineness into the stability and clarity of geometric space.

\section{The Illusion of Perceptible Essences}

Another example discussed by Wittgenstein is found in the use of a single word to denote an array of items that bear a "family resemblance" to one another-i.e., items that share some qualities but not others. When such items are grouped together under one word, a reified picture is created of an essence that each of them instantiates. Psychiatry's Diagnostic and Statistical Manual, for example, will present several symptoms that are claimed to be characteristic of a diagnostic entity, say depression, 
and a patient is said to be afflicted with this disorder if a certain proportion of those symptoms are manifest. That is, people whose sufferings bear a family resemblance to one another become, through the reified picture that has been named, instantiations of a metaphysical diagnostic essence, an essence that can somehow be directly perceived through some form of "eidetic intuition" (Husserl, 1913/2001).

\section{The Illusion of Transparency}

Consider again, briefly, the word mind, a term showing a great many meanings, depending on its particular contexts of use. In one of these, a picture commonly visualized is of an entity having external boundaries and an interior with contents. As noted earlier, the spatial interiority of such a picture reifies and absolutizes the subjective sense of "minenesss", metaphysicalizing the experience of one's perceptions, thoughts, and feelings being one's own. When one thinks of oneself and others as possessing minds, something that may seem to be as incontrovertible as the proposition that the sun rises in the morning, experiential lives acquire a dimension of "inwardness" separating the experiencing subject from "outer" reality. In actual language use, the pictures accompanying the use of this word fluctuate, in a kind of dance of variations in which what is denoted and connoted, visualized and absolutized, shifts from moment to moment in synchrony with changes in its context.

Imagining the meaning of the term mind to coincide fully with its associated picture, one may also presuppose that this meaning is shared by others. The use of the word in conversation is accordingly regarded as transparent to the other, who is presumed to live in a common world and to be in contact with exactly that of which one speaks. But how can one know that the meaning of this term, and really of any word one uses, is the same for the other as it is for oneself?

Perhaps the illusion of transparency, of absolute equivalency of meaning, serves as an antidote to a painful sense of isolation accompanying the finitude of intersubjective relatedness. One person can never know with absolute certainty the experience of the other, the only possibility being a succession of ever-closer approximations. Could it be that by embracing universalized pictures of the meanings of the words one uses and diverting one's gaze from all the deficiencies and ambiguities in mutual understanding, one is shielded from an otherwise unbearable feeling of being alone?

\section{The Tragic and the Metaphysical}

The first Western philosopher to examine systematically the relationship between the tragedy of human finitude and the ubiquity of metaphysical illusion was Wilhelm Dilthey (1910/2002). As is elegantly reconstructed by de Mul (2004), Dilthey's life's work can be seen as an effort to replace the Kantian a priori-the timeless forms of perception and categories of cognition through which the world becomes intelligible to us - with "life categories" that are historically contingent and constituted over the course of a living historical process. There is a tragic dimension to Dilthey's historical consciousness, in that it brings out the "tragic contradiction between the philosophical desire for universal validity [the metaphysical impulse] and the realization of the fundamental finitude of every attempt to satisfy that desire" (de Mul, 2004, p. 154). Dilthey's recognition of this tragic contradiction leads him to elaborate a hermeneutic 
phenomenology of metaphysics. Dilthey's historical reconstruction of the development of metaphysics aims at no less than its "euthanasia". Although he holds that metaphysical desire is inherent to human nature, what he seeks to unmask are the illusions that this ubiquitous desire creates. Metaphysical illusion, according to Dilthey, transforms historically contingent nexuses of intelligibility-worldviews, as he eventually calls them-into timeless forms of reality. Anticipating Heidegger (1927/1962), Dilthey holds that every worldview is grounded in a mood regarding the tragic realization of the finitude of life. The metaphysicalization of worldviews transforms the unbearable fragility and transience of all things human into an enduring, permanent, changeless reality, an illusory world of eternal truths. Dilthey grasps the metaphysical impulse as a relentless tendency to transform the experience of the real-how entities are intelligible to us - into a reified vision of the REALLY real. In this essay we have contended that a certain feature of the phenomenology of language - the prereflective presumption that words refer to pictures and that the pictures depict metaphysical entities-plays a constitutive role in such illusory transformations.

\section{Metaphysical Illusion in Everyday Life}

An understanding of the reified pictures that are associated with the words one uses leads to the idea that people generally are metaphysicians. Assuming that the words that are spoken have fixed, universally transparent meanings, one is lulled away from an anxious appreciation of the contingent, ever-shifting nature of intersubjective life. What are the interrelated dimensions of experience that are engaged in this metaphysicalization of everyday existence?

One of these is that of solidity - the sense of the tangible, of the physical, of the dense and heavy. If one's words have no fixed and absolute meanings, the very foundations on which one stands threaten to dissolve into thin air.

A second dimension is one of continuity, an experience of the sameness over time of the various things of which one speaks. The pictures evoked by the words that are used are of entities showing a reassuring stability from each moment to the next, offering protection against a descent into temporal chaos.

Still another dimension is that of coherence. The pictures that one assumes capture the meanings of what is said are of wholes, of parts that form a unity or identity that is felt to exist in its own right. Stripped of such coherence, all the things of one's world, including other people and one's own very selfhood, collapse into an unbearable indeterminacy.

What would happen to the human experience of language and communication if the reified pictures one imagines as the meanings of the words that are spoken, transparently available to all, vanished and were replaced by an ongoing sense of those words' fluidity as they are used in varying contexts? What if the felt certainties accompanying our verbal exchanges with one another melted into an ever-changing incoherence and insolidity? By metaphysicalizing the words and meanings of everyday discourse, human beings confer a calming order on their experiences of life and the language used symbolically to represent them. The very same linguistic 
capacities that make possible the disclosure of human finitude also provide the means by which the tragedy of finitude is evaded.

\section{Concluding Remarks}

Most often the term finitude is used to denote temporal limitedness-mortality. But the term can be seen to encompass all the ways in which finite human existing is limited, and each can be a source of traumatic emotion (Stolorow, 2007). For example, as we have noted, there is also the impossibility of clear and certain knowing and the corresponding finitude of intersubjective relatedness. Human beings must navigate these multiple dimensions of finitude, and they do so by creating a multitude of countervailing metaphysical illusions that serve to evade or counteract the corresponding traumatic affect. Far from being distinguished by being an animal rationale, the human being, as Dilthey recognized, is a being who cannot exist without metaphysical illusion, and such illusion, as Wittgenstein understood, is made possible by the phenomenology of language. Unlike Dilthey, who largely reserved the metaphysical impulse to abstract philosophical systems, we have extended it to everyday life as well. And unlike Wittgenstein, who believed that the bewitchment of intelligence by language could be overcome by good philosophizing, we contend that such bewitchment is an indelible feature of the never-ending struggle against the tragedy of finitude.

\section{Biographical Note}

Robert D. Stolorow and George E. Atwood have been absorbed for more than four decades in the project of rethinking psychoanalysis as a form of phenomenological inquiry. Dr. Stolorow is a Founding Faculty Member at the Institute of Contemporary Psychoanalysis, Los Angeles, and at the Institute for the Psychoanalytic Study of Subjectivity, New York. He is the author of World, Affectivity, Trauma: Heidegger and Post-Cartesian Psychoanalysis (Routledge, 2011) and Trauma and Human Existence: Autobiographical, Psychoanalytic, and Philosophical Reflections (Routledge, 2007) and coauthor of eight other books. Dr. Atwood was a Professor of Psychology at Rutgers University from 1971 to 2012, and he is a Founding Faculty Member at the Institute for the Psychoanalytic Study of Subjectivity, New York. He is the author and coauthor of many articles and books in psychoanalysis, including The Abyss of Madness (Routledge, 2011). He maintains a private practice of clinical psychology in Providence, Rhode Island.

\section{References}

de Mul, J. (2004). The tragedy of finitude: Dilthey's hermeneutics of life. New Haven, CT: Yale University Press.

Dilthey, W. (2002). Selected works: Vol. 3. The formation of the historical world in the human sciences. Princeton, NJ: Princeton University Press. (Original work published 1910)

Heidegger, M. (1962). Being and time (J. Macquarrie \& E. Robinson, Trans.). New York, NY: Harper and Row. (Original work published 1927) 
Husserl, E. (2001). The shorter logical investigations (D. Moran, Ed.). New York, NY: Routledge. (Original work published 1913)

Inkpin, A. (2016). Disclosing the world: On the phenomenology of language. Cambridge, MA: MIT Press.

Stolorow, R. D. (2007). Trauma and human existence: Autobiographical, psychoanalytic, and philosophical reflections. New York: Routledge.

Stolorow, R. D. \& Atwood, G. E. (2013). The tragic and the metaphysical in philosophy and psychoanalysis. Psychoanalytic Review, 100, 405-421.

Wittgenstein, L. (1953). Philosophical investigations. Malden, MA: Blackwell Publishing.

Wittgenstein, L. (1993). Remarks on Frazer's Golden Bough. In Philosophical Occasions 1912-1951 (J. Klagge \& A. Nordmann, Eds.). Indianapolis, IN: Hackett Publishing. (Original work published 1967)

Zahavi, D. (2005). Subjectivity and selfhood: Investigating the first-person perspective. Cambridge, MA: MIT Press. 